\section{RELATO DE PESQUISA}

ABSTRACT: This text discusses the questions and investigate the representation of light in both photographic and pictural langages. It also traces the ambivalent imagery of the illumination in the "ex-voto" paintings and surveys the interactions between photography and painting. Based on a personal work in painting, the text is focused on the way the photographic immagery is translacted into painting, and traces the link between the representation of illumination and the idea of the spiritual in art.

KEYWORDS: Transformation; Photographic; Votive offering; intersection.

RESUMO: Este texto discute e investiga questões referentes à representação da luz tanto na linguagem fotográfica como na linguagem da pintura. $O$ autor procura estabelecer ligações entre a representação da iluminação nos "ex-votos" cênicos e na fotografia, e, de uma forma ampla, trata da interação entre a fotografia e a pintura. Baseado em um trabalho plástico pessoal, o texto focaliza o modo como o fotográfico é absorvido pela representação pictórica. De uma forma especifica, trata da questão da iluminação como idéia de espiritualidade em arte.

PALAVRAS-CHAVE: Transformação; Fotográfico; Ex-votos; Intersecção.

\section{EDUARDO VIEIRA \\ DA CUNHA}

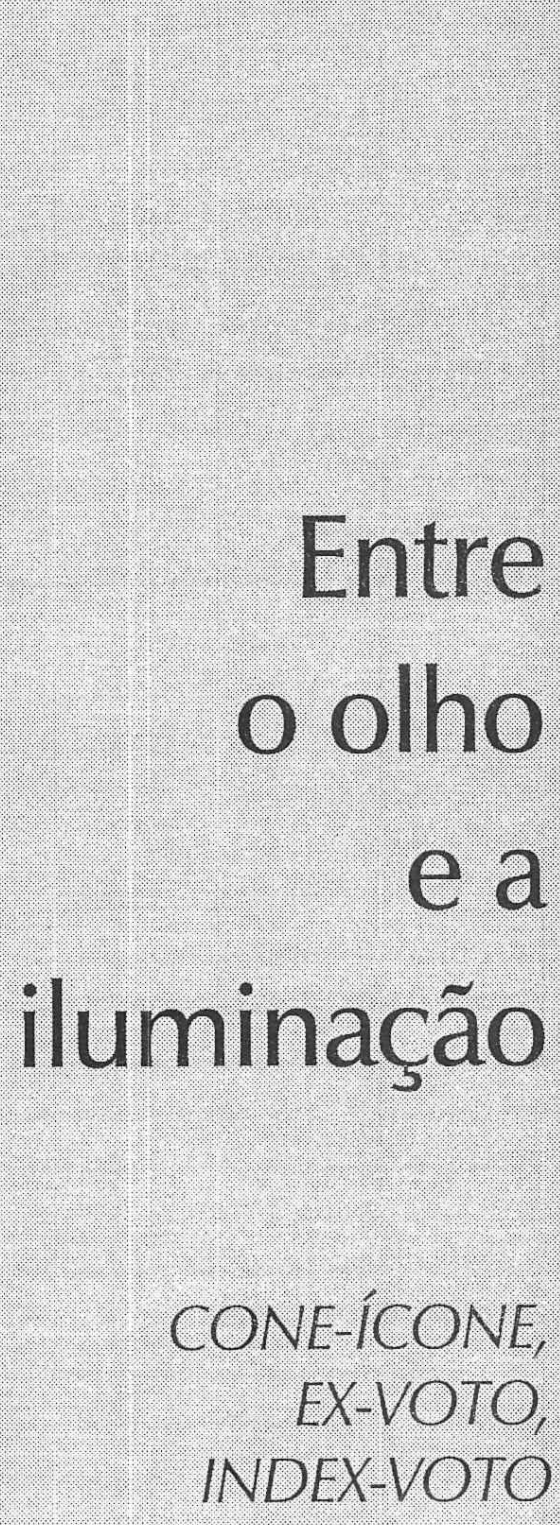

Porto Arte, Porto Alegre, v.9, n. 16, p. 105. 120, mai. 1998 
M

inha pesquisa em Artes Plásticas teve por objetivo abordar um processo de transformação. Transformação não só de todos os elementos que a fotografia me revelara depois de ter trabalhado durante muito tempo como fotógrafo, mas também transformação de uma visão. A máquina fotográfica que, em um primeiro momento, intercala-se como uma prótese entre mim e os objetos para permitir o conhecimento da luz, é em seguida descartada. Como uma imagem latente, a visão fotográfica não se revelará à consciência senão mais tarde, através de um processo de reflexão. Descobrir alguma coisa é manifestar não algo de novo, mas algo de despercebido, de desconhecido até então. Gostaria de evocar aqui a percepção e a aprendizagem da luz através da fotografia bem como as operações sucessivas de transformação, de tradução do material luminoso para ir na direção de uma iluminação pictural.

Minha hipótese é baseada em dois questionamentos. O primeiro refere-se à minha trajetória de fotógrafo e de pintor: como e por que vias o fotográfico, como imagem intermediária, revela-se em minha pintura e quais as marcas do fotográfico na iluminação pictural. O segundo examina a relação entre a linguagem fotográfica e a linguagem dos ex-votos e pesquisa na iluminação - ou na luminosidade — dos ex-votos brasileiros os lugares onde se poderia detectar a presença das marcas do divino.

\section{A PROPÓSITO DO FRAGMENTO NA FOTOGRAFIA E NO EX-VOTO}

A fotografia tem o poder de retalhar ao infinito as imagens do universo, de fazer surgir detalhes, fragmentos que se tornam objetos independentes de seus modelos. Esta especificidade da imagem fotográfica que seria a de nascer por pedaços e que afirma na arte o status autônomo do fragmento, do corpo retalhado, e isso, desde os primeiros anos da fotografia, está presente já nos ex-votos. Status de instrumento do artista, justificação pragmática de uma pedagogia do desenho no ateliê, ou até como instrumento de investigação e de representação científica, o corpo fragmentado pela fotografia situa-se no encontro da arte e da ciência, como pôde demonstrá-lo a exposição $A$ arte do Nu no século XIX, o fotógrafo e seu modelo ${ }^{1}$. É da mesma maneira que um outro gênero de objetos - peças anatômicas moldadas diretamente sobre seu referente inscreve-se na história da representação. Ligadas aos cultos funerários (máscara mortuária), ao estudo científico (anatomia e patologia) e a uma intervenção sobrenatural (ex-voto), elas nos lembram o sentido da morte.

Para Georges Didi-Huberman²," a marca reificada dos corpos, restituída em tiragens positivas, confundiu-se em boa parte com a operação - com o próprio recorte - anatômica. Sabemos todos, mais ou menos obscuramente, que a anatomia designa em nós um "destino": o de nosso despedaçamento observável por outrem, o de nossa morte visualizada". 
Didi-Huberman coloca também uma questão importante na história da fotografia e de sua relação com a pintura (o fotógrafo anônimo), como no ex-voto - a saber a qualidade do autor" : "Por que as moldagens mortuárias, bem como os ex-votos ou as ceras anatômicas não fazem parte de uma história da escultura no sentido estrito — ou ao menos no sentido usual - do termo? Por que não são elas objetos para a história da arte entendida como disciplina "humanista" e como disciplina "autônoma"? A resposta parece evidente por si: por mais soberbamente realistas ou realizados que sejam, esses objetos, em geral não foram produzidos por artistas e também não foram produzidos por amadores de arte, salvo casos de perversão caracterizada. Ligado aos cultos funerários e aos restos do corpo, o horizonte antropológico da impressão parece bem estranho a tudo o que lemos geralmente nas obras dedicadas à arte estatuária."

Na arte contemporânea, a fragmentação tornou-se uma possibilidade. De simples instrumento do artista, adquiriu o status de uma obra que se expõe, graças às ressonâncias que desperta em um olhar contemporâneo. Por repercussão, nota-se aí uma transformação do olhar que modifica uma imagem e suas significações na história. As obras de John Coplans (fragmentação do corpo), Christian Boltanski e Annette Messager (ex-voto) oferecem exemplos disso (figuras 1, 2 e 3).

\section{À LUZ DE UM CONE}

Para mim, a vida alicerça-se em duas operações de transformação: sendo uma a absorção e a transformação da energia, a outra, a absorção como transformação e produção da informação. As operações plásticas que efetuo pertencem a este último processo. Em uma relação triangular entre a fotografia, a iluminação e a pintura, os indícios fotográficos tornam-se signos icônicos. Um dispositivo projetivo é integrado nas composições pictóricas. Organiza-se a partir de uma câmera, que, a exemplo de um ampliador fotográfico, projeta um cone de luz, definindo assim um perímetro em cujo interior registram-se as metamorfoses do sentido (figura 4). A câmera aqui tem a função de prótese visual, de intermediária entre duas realidades; uma lanterna acesa em pleno meio-dia para anunciar a presença de um ato de transformação (figuras 5 e 6).

A fotografia é uma alteração do real, pois ela recorta e reproduz o mundo por fragmentos. Lemos as fotografias fatia por fatia, elemento por elemento. Penso que essa prótese desempenhou um papel importante em minha aprendizagem da iluminação. Este processo de leitura de uma imagem intermediária, o recorte e a possibilidade da reprodutividade fotográfica de uma forma isolada da inscrição luminosa levaram-me a uma análise específica da iluminação. Para estabelecer uma analogia com o princípio fotográfico, penso que a percepção da luz ficava como imagem latente em minha consciência de artista plástico, para se desenvolversomente após ter sido transformada por uma forma de iluminação.

\section{A BUSCA DE UMA PRÁTICA}

Trabalhei como fotógrafo de imprensa durante vários anos, no Brasil, onde 
a luminosidade é especial. A iluminação não é mais apenas um modo imediato de comunicação, mas também um meio de influência sobre o olhar do espectador. Para Max Kozloff ${ }^{4}$, as condições da luz natural na América Latina, por causa de um contraste muito forte entre sombras e luzes, são quase dramáticas. Mais tarde, a mesma fantasmagoria luminosa, os jogos de sombras e as silhuetas recortadas foram transportadas por mim para um outro meio - a pintura. Um pouco como um paciente que, tendo acabado de receber o diagnóstico de seu médico, exige conhecer a natureza precisa de sua doença, eu gostaria de analisar o momento desta transformação e a passagem de um meio ao outro, da fotografia à pintura.

Do mesmo modo que próteses colocadas nas igrejas como objetos da promessa, a máquina fotográfica torna-se, em determinado momento de meu trabalho, o membro artificial. Após ter abandonado a fotografia como modo de expressão, procuro um meio de registrar a presença do fotográfico em minhas imagens. Noto, através da representação de um cone de aumento, a presença de resíduos sensoriais, os "index-votos" da fotografia. Os vestígios dissolvem-se em um elemento líquido, a água dos glacis, segundo um processo de construção-transformação de uma imagem desde a superfície projetiva do aumento à tela recoberta de gesso, metáfora da luz divina.

A composição dos quadros votivos é condicionada por algo que emerge em uma projeção celeste, um contato muito oportuno entre o Cristo, a Virgem, ou os santos e os homens. Há sempre uma espécie de decantação que se produz no olhar dessas imagens, para uma iluminação particular e uma surpresa com a aparição. Essa surpresa está presente também nos exvotos anatômicos que constituem uma verdadeira instituição no Brasil. Eles consistem em fragmentos de corpos, fabricados em cera e têm a significação simbólica de uma prótese ou de um agradecimento pela cura. Esses objetos são colocados nas igrejas, em locais precisos onde recebem sempre uma luz em sentido inverso daquele do olhar, uma teatralização, uma exibição e uma iluminação translúcida de suas propriedades. A luz torna-se então uma iluminação que transpassa fixando as sombras em suas transparências, como um negativo fotográfico (figura $\mathrm{n} \cong$ 7). Essa luminosidade junta-se à luz divina que atravessa o gesso nas transparências da pintura (glacis).

\section{COMPREENDE A LUZ E CONHECE-A}

A luz fotográfica torna-se um signo icônico. Procuro constituir, com meios pictóricos, um universo autônomo de luz, uma iluminação que resulta de lembranças e de percepções anteriores. Partindo de uma organização de estímulos naturais (a luz), trabalho para obter um resultado artificial (a iluminação).

Além de associar intimamente realidade e ficção, a iluminação põe em jogo também uma série de referências particulares. Ela fascina. Seu brilho é simultaneamente trágico porque teatral, e divino por- 
Entre o olho e a iluminação ?1: 109

que é a manifestação da pureza. Ela é a fonte de tudo na fotografia e na pintura.

A luz sempre foi percebida como um elemento de metamorfose que age sobre os conceitos, as impressões sensíveis e o mundo do espírito. É sob a forma de imagem luminosa que os defuntos aparecem nas sessões espíritas do século XIX. Os iniciados da cabala e da gnose são chamados "iluminatti", os iluminados. O caráter dramático dos ex-votos cênicos é sempre exaltado por uma iluminação divina na obscuridade dos arrebatamentos da natureza.

A luz da pintura acadêmica foi mimética. Duchamp transformou este conceito integrando a luz à obra plástica, como restabeleceu a distinção entre percepção e concepção na prática artística. A função da luz não é somente clarear, tornar visível uma obra. O caráter mutante dessa matéria singular, as transformações e os efeitos de passagem, o visível e o invisível, a manipulação e o conceito de uma imagem intermediária, o caráter diáfano de uma aparente imaterialidade que parece conferir-lhe uma origem divina, todas essas características constituem outros tantos motivos de especulações sobre a dimensão física da luz.

Esta pesquisa teórica parte de uma constatação sobre meu trabalho em pintura: a concepção de uma percepção fotográfica ou uma transformação. Minhas imagens são estruturadas pela plenitude e pela ausência da luz. Elas se elaboram a partir do preto e branco (o da fotografia) para ir rumo a uma colorização. A força física da luz e a da obscuridade fotográ- fica estão presentes, mas as relações temporais e físicas diferem daquelas da fotografia. A preparação das telas, por exemplo, é uma fase muito importante em meu trabalho plástico. Camadas sucessivas de gesso são depositadas sobre a tela a fim de obter uma superfície branca uniformemente reverberante e difusora como uma metáfora da luz divina. Os glacis são utilizados em todas as operações que se seguem, segundo um processo de substituição e de transformação em que elementos aparecem e desaparecem, como em um laboratório.

A tradição ocidental tem duas metáforas supremas, a consciência e Deus. Robert Grosseteste, em sua obra Dans la lumière, ou l'avènement des formes ${ }^{5}$, propõe uma combinação de filosofia neoplatônica e aristotélica que exprime uma teologia, uma ontologia e uma cosmologia da luz. Segundo Grosseteste, há dois sistemas de transformação:

1) Transformação numerológica (homóloga do sistema alfabético): "Todos os corpos não têm a mesma forma, mesmo que tenham sua origem em uma luz elementar. Do mesmo modo que os números não têm a mesma forma, ainda que sejam todos múltiplos maiores ou menores do que a unidade; cada vez que se adiciona o número um da forma e o número dois da matéria e o número três da composição e o número quatro da totalidade, eles formam o número dez. Dez é o número da plenitude do universo, pois todas as coisas inteiras e perfeitas encerram, de alguma maneira, a forma, que depende da unidade e da matéria, que depende do 
número dois, e da composição, que depende do número três, e da totalidade, que depende do número quatro e àqueles quatro não é possível acrescentar um quinto. Por conseguinte, todas as coisas planas e perfeitas são um dez. Mas daí segue-se necessariamente que só as cinco relações entre seus quatro números: um, dois, três e quatro convêm a esta harmonia que faz a constância de toda composição".

2) A transformação ontológica: "A matéria dos quatro elementos foi reunida na nona esfera, que é a esfera da lua. A nona esfera, gerando o dia a partir dela mesma e reunindo a massa nela mesma, produziu o fogo. O fogo, gerando a luz, produziu o ar. $\mathrm{O}$ ar, gerando a partir dele mesmo um espírito corporal, produziu a água da terra. Mas a terra constitui todos os corpos superiores, pois todos os dias superiores se acharam comprimidos na terra, e a luz de toda esfera pode ser extraída da terra para se encarnar em atos e operações."

\section{A INTENÇÃO ESTÁ NA MÃO}

Em meu processo de trabalho, a água está sempre presente sob forma de glacis (figura 8). A imagem sobre o suporte luminoso não surge bruscamente, toda inteira mas seguindo uma transformação lenta e progressiva das transparências, com a interferência da mão. O fogo é representado pelo duplo efeito de combustão da luz solar e do trabalho sobre a iluminação artificial. A metáfora da criação está presente como uma alegoria platônica em que a luz é colocada no miolo do entendimento humano - compreende, então, a luz e conhece-a.

Philippe Dubois, em L'acte photographique $^{6}$ introduz a referência a Deus e à criação humana como modelo original da representação: "Tomar por modelo da representação a Criação do homem por Deus é a uma só vez remeter explicitamente o nascimento da pintura (e da escultura) à imemorialidade mítica de toda origem (ao "tempo da origem de todas as coisas") e é também instituir Deus como Grande Pintor Original. Por extensão, é fazer de todo pintor não exatamente um deus, um creator ex nihilo, mas um sujeito que já foi criado e que não se limita a copiar, reproduzir (imperfeitamente) a obra e o gesto do Grande Genitor, a partir dos próprios materiais que emanam da Criação dEste (creatura non potest creare disse Santo Agostinho)". A ação de transformar é a operação pela qual se, isto é, a mão do homem, modifica as coisas a partir desse modelo original. A idéia de uma transformação da matéria e de um "estado de coisas" que leva os corpos a conhecerem diferentes estados: sólido, líquido, gasoso, deve ser ligada aos desenvolvimentos da ciência, passando pelo controle da mão humana. A mão pode ser encarregada de numerosas significações como a ação, o poder, humano ou divino. A mão é também uma antropomorfização do divino. Ela é mais do que um organon: é o símbolo de um processo de transformação (figuras 9 e 10). 


\section{INFLUÊNCIA LATENTE}

Este enunciado aspira a ser também esclarecedor quanto às circunstâncias da passagem de um meio de comunicação a outro. O processo de criação necessita uma série de competências, de métodos desenvolvidos graças à experiência. $\mathrm{O}$ trabalho de criatividade é misterioso, desordenado e feito de aprendizagens. Para nós, a análise comparativa entre as pinturas e suas fontes pode acarretar uma melhor compreensão, dar informações relevantes sobre os diferentes procedimentos aos quais cada artista se engaja para realizar sua obra, o que o artista não diz, o que ele modifica ou o que guarda da fonte em seu trabalho acabado, o que ele dissimula e até como e sob que forma apresenta ao público essas fontes ou as omite, permitindo ou não uma intrusão no processo tão particular que é o da interpretação da realidade tratada.

O termo "influência" vem da doença "influenza", isto é, algo que se contrai involuntariamente. O fotógrafo brasileiro Sebastião Salgado, em uma entrevista publicada pela revista "Photoptica", referese a um aspecto particular que gerou uma revelação em seu trabalho: "Após vários anos de trabalho, após milhares e centenas de clichês realizados, alguém, a propósito de minhas fotos, fez uma observação sobre a luz, sublinhando um aspecto que eu nunca havia percebido: os objetos, as pessoas, são aí sempre fotografados à contraluz. Subitamente, voltou-me à memória a luz de meu país, da cidadezinha onde cresci, no interior de Minas Gerais, no Brasil. A luz lá é tão intensa que tudo fica como que imobilizado, suspenso por ela ou submerso pela sombra. Minha visão foi condicionada pelos extremos do dualismo luz-sombra de meu país" (figuras 11 e 12).

Lévi-Strauss, em "Tristes Trópicos" evoca a luz do Brasil: "Depois de tantos anos, conseguirei recolocar-me neste estado de graça? Poderia eu reviver esses instantes febris em que, caderneta na mão, anotava segundo após segundo a expressão que me permitiria talvez imobilizar essas formas evanescentes e sempre renovadas? $\mathrm{O}$ jogo ainda me fascina e freqüentemente me ponho a me arriscar nele." Esta visão da natureza enquanto signo, enquanto representação, da matéria enquanto escrita, a imagem fixa do tempo imobilizado é propriamente fotográfica. Também fotógrafo, Lévi-Strauss dá a visão de um observador atento à luz do Brasi ${ }^{9}$ "A Europa oferece formas precisas sob uma luz difusa. Aqui, o papel, para nós tradicional, do céu e da terra inverte-se."

O compositor e escritor brasileiro Chico Buarque de Hollanda ${ }^{10}$ em uma canção intitulada "Brejo da Cruz", transcrita na obra "Terra", de Sebastião Salgado, fala de crianças que "se alimentam da luz", para "eletrizar, cruzar o céu do Brasil".

Philippe Dubois remete também para "corpo da luz"11: "A fotografia é apesar de tudo uma curiosa questão de luz, ou melhor, de circulação da luz com tudo o que essa questão implica de tenebroso. Creio que é necessário hoje repensar toda a fotografia no âmbito de uma economia geral da luz que concerne não somente à fotografia só, mas também, na mesma 
circulação, ao cinema, ao vídeo e à pintura. Partamos do mais banal. Para tirar um retrato, é preciso, claro, que haja luz que ilumine o sujeito. É preciso que este irradie, que a luz emane dele para atingir e queimar esta "película tão sensível", tão reativa a suas emanações, que guardará dela a impressão Ao mesmo tempo e paradoxalmente, é preciso também que essa luz cesse de existir, desejando-se que a imagem finalmente apareça: a revelação faz-se na câmara escura".

\section{A CÂMARA ESCURA}

Durante os anos em que eu trabaIhava como fotógrafo de jornal, a câmara escura representou um capítulo especial. Venho do sul do Brasil e durante dez anos fui correspondente de um jornal do Rio de Janeiro - O GLOBO - , que me encomendava reportagens de jornal em imagens, baseadas no encontro entre um acontecimento fortuito e o fotógrafo. Um e outro estavam sempre distantes cerca de dois mil quilômetros da sede do jornal aonde as fotos deviam no entanto chegar no mesmo dia. Por isso, como os fotógrafos dos primórdios da fotografia, eu tinha a obrigação de viajar com uma câmara escura portátil, que me permitia transformar os quartos de hotel em laboratório. Fossem quais fossem as condições, era preciso que eu me achasse lá no momento mesmo em que o evento acontecia, como era preciso que a fotografia chegasse ao jornal no mesmo dia. O sistema de transmissão, por linha telefônica (telefoto) não reproduz muito bem os contrastes mais acentuados dos tons entre luz e sombra. Meu trabalho na câmara escura sempre consistiu em "transformar" a luz particular da América Latina que reforça os contrastes, em escurecer as luzes demasiado brancas, em clarear os fundos demasiado sombrios com valores semi-grisáceos que a máquina poderia transmitir. Este procedimento é análogo a uma manipulação pelo fogo que queima a superfície branca do papel fotográfico sem tocar o filme brilhante, gelado, superfície lisa. Como uma lanterna mágica (figura 13). Esta preocupação encontra-se também em uma série de desenhos que realizei na mesma época (figura 14) em que concedo um largo espaço aos tons em semi-gris, sem zonas de pretos ou de brancos puros. A gama contínua dos grises é obtida aí por linhas muito finas e ininterruptas. Como o princípio da imagem fotográfica, a importância do processo vem a mim após uma fase de latência, para aflorar à consciência em um outro momento, o da reflexão. A preparação de uma câmara escura, as imagens apagadas pela luz na câmara escura aberta um instante demasiadamente cedo, clarear uma câmara escura, todas essas imagens apresentaramse em meu trabalho.

Na realidade, a necessidade de "contar a história" de um evento propriamente dito, sempre presente em meus desenhos como em minhas pinturas ulteriores, vem do ofício de fotógrafo de jornal. A linguagem clássica da pintura acadêmica que uso é motivada também pela idéia de transpor o observador, de torná-lo presente nas paisagens distantes. Desta maneira, este pode ter a sensação de participar da ação. É uma linguagem idêntica à da ópera, à dos documentários de cinema. 


\section{TRADIÇÃO E RUPTURA}

Os países da América Latina têm como denominador comum a busca e a justificação de um sentido ou de uma significação socideológica para a atividade artística. Nesta ótica, pode-se pôr em relação a ideologia e a fotografia, que apresentam alguns pontos comuns. O primeiro é a contemporaneidade de sua origem: a fotografia e a teoria da ideologia nascem quase ao mesmo tempo. Nièpce e Daguerre descobriram o daguerreotipo na terceira década do século XIX. O termo "ideologia" e uma certa reflexão surgem no século XVIII com Destrut de Tracy, ${ }^{12}$ mas a formulação de uma verdadeira teoria não se exprime senão em 1845 com Marx e Engels.

Resultante do desenvolvimento tecnológico do século XIX em uma sociedade cada vez mais complexa e que necessita novos meios de expressão, a fotografia e a ideologia comunicaram-se desde o início. Como lembrança, evoquemos o interesse dos primeiros fotógrafos pelos conflitos sociais, ideológicos e políticos pouco depois da revolução industrial. De outra parte, Marx, Freud e Nietzsche ${ }^{13}$ usam metáforas óticas e fotográficas para explicar o processo ideológico. A linguagem iniciante dos precursores, a angústia para falar de algo novo, sem uma nomenclatura própria, levaram Marx e Engels ${ }^{14}$ a adotar metáforas como "câmera escura" e "reflexo" para descrever a inversão ideológica na representação do real. Já Freud escreveu que a psiquê é semelhante a uma câmera, pois que todo o fenômeno passa por uma fase inconsciente, pela obscuridade, o negativo, antes de aflorar à consciência.

Mas há sempre o risco de reduzir a atividade artística a uma função social, a um panfleto, sobretudo na América Latina, onde os problemas de autoritarismo foram numerosos nestes últimos anos. Esta realidade acabou por determinar um liame político muito discutido no que concerne aos artistas latino-americanos.

\section{REFLEXO INVERTIDO}

Quando Marx se refere idealmente ao determinismo da matéria, usa imagens ligadas à fotografia: apresenta a ideologia como um conjunto de reflexos invertidos em relação à realidade, como é a imagem em uma câmara escura ${ }^{15}$. Esta metáfora, tornada conceito, criou um mecanismo de interpretação dos produtos culturais. Dizse freqüentemente que a obra "reflete" a ideologia de seu autor. O reflexo ideológico foi concebido como externo à realidade, da mesma maneira que o reflexo ótico situa-se frente à sua fonte. Havia uma tendência a ver o determinismo da realidade como casual, mecânico e unidirecional, quando, ao contrário, ele é estrutural, reversível e multidimensional. Umberto Ecco, em L'oeuvre ouverte ${ }^{16}$ remete a uma dupla organização do estímulo estético: "Podemos notar que se a divisão da linguagem em referencial e emocional permitiu-nos abordar o problema da utilização estética da linguagem, não é ela, em compensação, que o resolve. Vimos que a diferença entre referencial e emocional não concerne 
tanto à estrutura da expressão quanto à sua utilização (e, por conseguinte, à situação na qual a frase é pronunciada). Vimos uma série de frases referenciais adquirirem, em dadas circunstâncias, um valor emocional. Poder-se-ia fazer a experiência inversa com expressões imperativas, na origem, portanto emocionais, e que, em certas situações, tornam-se referenciais: em uma auto-estrada italiana, a sinalização "Atenção" indica sem equívoco possível a proximidade de uma via de entrada ou de saída. Na realidade, a utilização de uma expressão com uma finalidade determinada (referencial ou emocional) joga sempre com duas possibilidades simultaneamente. A este respeito, o caso de algumas comunicaçốes sugestivas é significativo: o halo emocional aí resulta precisamente de que o signo utilizado por sua ambigüidade é ao mesmo tempo recebido como uma referência precisa. O signo "Minos" manuseia a realidade cultural e mitológica à qual ele se refere inequivocamente, ao mesmo tempo que a onda de emoções que se associa à lembrança da personagem e a reação instintiva às sugestões fônicas que ele suscita, as quais são, por sua vez, mescladas de referências confusas e esquecidas, de hipóteses concernentes a significações possíveis e significações arbitrárias."

Ecco recorre em seguida à teoria da metáfora para se referir, na expressão artística, a uma utilização emocional das referências e a uma utilização referencial das emoções. "A reação sentimental tem por finalidade precisamente dirigir a atenção para uma zona de significação; prevêem- se e suscitam-se referências que não são absolutamente unívocas e emoções que têm uma precisão, ligadas ao termo que as suporta. Tudo isso se opera através de uma identificação, no material, do significante e do significado, do "veículo" e do "teor". Em outros termos, o signo estético é aquele que Morris chama de um signo icônico: a evocação semântica não se esgota na referência ao denotatum, mas enriquece-se cada vez que se frui a maneira insubstituivel pela qual se incorpora ao material que the fornece sua estrutura; a significação retorna continuamente ao signo e se enriquece assim com novos ecos."

\section{UMA RETA QUE LIGA DOIS PONTOS}

No inverno de 1921, o jovem poeta Jorge Luís Borges chega a Buenos Aires com a firme intenção de mudar o panorama artístico e literário da Argentina. Lança a revista literária mural Prismas tendo como objetivo "iluminar com lâmpadas verbais todas as ruas, as estradas, as paisagens tomadas à fotografia ${ }^{17}$ para falar do fenômeno artístico: "Há dois tipos de estética, a estética passiva do espelho e a estética ativa dos prismas. No primeiro, o indivíduo é o reflexo passivo do ambiente e no segundo, o ambiente é o instrumento do indivíduo. Os dois podem existir conjuntamente. Eu busco a sensação pura, não as descrições das primícias espaço-temporais que os cercam. A metáfora é indispensável para obter o elemento luminoso, como uma trajetória verbal que traçasse o caminho mais curto entre dois pontos." 
Borges, em 1938, opõe-se ao Manifesto por uma arte revolucionária ${ }^{18}$ em que Breton e Rivera preconizam uma arte "engajada nos ideais revolucionários" e clamam que a "a tarefa suprema da arte é a de preparar a revolução e de participar dela ativamente, com os meios da arte". Nessa época, Breton, como outros surrealistas, exilou-se na América Latina ${ }^{19}$ onde influenciaram consideravelmente os artistas latino-americanos. Esta espécie de "apelo à ordem" contido no manifesto provoca em Borges uma reação de indignação ${ }^{20}$. Para Borges, o texto de Breton e Rivera é "contraditório, autoritário, uma imposição de um projeto estético coletivo que inibe a iniciativa individual". Todavia, as manifestações do Grupo Surrealista em 1939 continuam ricas de ecos da viagem de Breton ao México. A América Latina adquire entre os surrealistas o status do "país onde o vento da liberação não esmoreceu" ${ }^{\prime \prime 2}$. É, por exemplo, o que confirmam tanto a pessoa quanto a obra de Frida Kahlo, "preciosamente situada neste ponto de intersecção da linha política (filosófica) e da linha artística, a partir do qual desejamos que elas se unifiquem em uma mesma consciência revolucionária sem que sejam levadas por isso a se confundirem os móbiles de essência diferente que as percorrem" 22 . Apesar da homenagem que lhe rende Breton, a artista mexicana manter-se-á à parte do surrealismo, mesmo após sua breve estada parisiense por ocasião da exposição "México", estimando de maneira geral que os intelectuais "envenenam o ar com teorias e ainda outras teorias que jamais se tornam reais."

\section{SURREALISMO}

Alguns retratos solarizados, aqueles dos poetas surrealistas em particular, dão a impressão de agarrar os últimos lampejos do que se chamava a glória, este astro eclipsado em proveito do sucesso. Mas eles testemunham também uma insolação do espírito enceguecido por sua própria luz, quando acreditava dissipar as trevas. (Gerard Macé)

A atitude de Breton em relação à fotografia é contraditória. Para Rosalind Krauss, ${ }^{23}$ dada sua aversão à figura real dos objetos reais, sua insistência sobre a necessidade de uma outra ordem de experiência, poder-se-ia pensar que Breton menosprezasse a fotografia. Enquanto meio de comunicação realista por essência, a fotografia deveria ser rejeitada pelo poeta que sustentara que “a obra plástica, para responder à necessidade de revisão absoluta dos valores reais sobre a qual hoje todos os espíritos concordam, refere-se portanto, a um modelo puramente interior, ou não existirá". ${ }^{24}$

Mas Breton refere-se à idéia de "norma" que sempre acompanha a fotografia. As manipulações permitidas pela fotografia asseguram uma presença constante do meio de comunicação entre os surrealistas. Para Rosalind Krauss" ${ }^{25}$, os conceitos de "beleza compulsiva", de "maravilhoso", de "escrita automática" e de "sonho", conceitos-chave do surrealismo, devem estar ligados diretamente ao meio fotográfico. 


\section{6 Ẽ- Eduardo Vieira da Cunha}

A montagem fotográfica - como instrumento de expressão infinitamente maleável, manipulável, que faz profundo apelo aos mais secretos desejos psicológicos - corresponde bem à regra surrealista. Também no plano espiritual, ela responde à necessidade de "maravilhoso" e à realização dos desejos inconscientes do sonho.

Penso que em minhas imagens busco essa poética da fotomontagem e do sonho tentando integrar, de uma parte, fragmentos fotográficos na composição, de outra, temas como o vôo, metáfora ligada a uma outra tradição especificamente fotográfica - a da fotografia aérea, recorrentes em meu trabalho (figura 15).

\section{FOTOGRAFIA AÉREA E VISÃO DO SONHO}

As imagens do sonho cujo vôo é tão desordenado, a cor tão frágil, a matéria tão transparente, são depositadas em nossas recordações por um cirurgião alfinetador de borboletas. (Gérard Macé).

Para Walter Frank, ${ }^{26}$ a interpretaçäo dominante do vôo parece determinante através de uma compreensão neokantiana da fundação do moderno, mas liberar o imaterial do quadro tecnicista que o organizou desde o século dezoito é inaugurar um pensamento plural e local do espaço. Ele cita o texto de Edgar Allan Poe ${ }^{27}-$ Loss of Breath em que o poeta, perdido na droga e no álcool, inventa visões distintas de um espaço diretamente acessível ao vôo - uma relação entre o levantar vôo e a visão do sonho.
Com Eléments suprématistes exprimant la sensation du vol, Kasimir Malevitch adota, desde 1914, uma estética próxima daquela da fotografia aérea. Para os suprematistas, esta está explicitamente vinculada às teorias de representação de um "novo espaço", sem horizonte nem profundidade, que eles desenvolvem na escola de arte de Vitebsk. Trata-se para eles de construir uma nova sensibilidade espacial que substitua as tradições herdadas da Renascença. A perspectiva é anulada e as noções de alto e de baixo, obsoletas. As relações com a fotografia aérea são evidentes uma vez que, para Malevitch, o suprematismo é uma nova maneira de sentir a existência, em que a inquietude torna-se uma excitação, uma sublimação que se compõem de noções aéreas: o espaço, o infinito, o abismo, a perda no precipício.

\section{FOTOGRAFIA AÉREA E TRANSFORMAÇÃO}

As relações entre o suprematismo e a fotografia aérea explicam-se também pelas transformações operadas por esta última que permite um formidável achatamento das formas, uma geometrização que vai até à abstração. Rosalind Krauss ${ }^{28}$ explicou esta potencialidade da fotografia, que transforma os signos terrestres habituais em sinais, códigos, indícios que necessitam uma interpretação: "é que choca, é que, contrariamente à maior parte das outras fotografias, a vista aérea levanta a questão da interpretação, da leitura. Não se trata simplesmente do fato de que, vistos 
Entre o olho e a iluminação

do alto, os objetos são difíceis de reconhecer - eles o são efetivamente mas mais especialmente disso que as dimensões esculturais da realidade tornaram-se muito ambíguas: a diferença entre as saliências e os vazios - o côncavo e o convexo - apaga-se. A fotografia aérea coloca-nos diante de uma "realidade" transformada em um texto, em algo que necessita uma leitura ou uma decodificaçăo. Há cesura entre o ângulo de visão do qual a foto foi tirada e este outro ângulo de visão que é requerido para compreendê-la. A fotografia aérea revela, pois, uma laceração no tecido da realidade, uma laceração que a maior parte das fotografias tiradas no solo tentam a duras penas dissimular. Se toda a fotografia promove e aprofunda nossa fantasia de uma relação direta com o real, a fotografia aérea tende - pelos próprios meios da fotografia - a rebentar o balão desse sonho."

Esta transformação do real é igualmente evocada por Philippe Dubois ${ }^{29}$ como um suprematismo ligado à concepção de um "novo espaço". Este ponto de vista suspenso e móvel é descrito por Philippe Dubois não como uma simples analogia, mas como um verdadeiro dispositivo teórico que põe em jogo a relação do sujeito com o espaço, da criação à percepção, da imersão do corpo à reparação do olhar (figura 16).

\section{EX-VOTO}

A propósito dos ex-votos, fiquei impressionado com o fato de que se encontrem aí os elementos da fotografia: olho, memória, impressões, sentido da morte, luz, iluminação, luminosidade, signo, objeto-imagem, lembrança, testemunho, elementos, surpresa, simbolização, substituição, transformação. Régis Debray ${ }^{30}$ evoca alguns retratos fotográficos como ex-votos: "Basta-me sabê-los lá, esses exvotos, em minha gaveta, para ter o sentimento de que eles me guardam, e quem sabe, me olham às vezes (...). Assumo e reivindico um uso ingenuamente sacerdotal dessas fotos."

No Brasil, os ex-votos anatômicos (consistentes em fragmentos de corpos, fabricados em cera) são uma verdadeira instituição. Nas regiōes Norte e Nordeste, as mais pobres do país, a prática é tão intensa que não sobra mais lugar nas igrejas para as oferendas. Os curas finalmente encontraram uma solução: as oferendas devem obrigatoriamente ser de cera e, após algumas semanas, são transformados em círios, vendidos em seguida nessas mesmas igrejas.

Fiquei impressionado com esta idéia de imagens-lembranças que servem de marcação mnemônica e que podem reproduzir-se à vontade, transformandose ainda em um outro dispositivo de memória (cera-círio-luz) e sua analogia com a metáfora fotográfica do "Wunderblok" de Freud apresentado por Philippe Dubois ${ }^{31}$. O ex-voto seria o intermediário, como um negativo, algo como um "entre-dois, a uma só vez da ordem do olho e simultaneamente da ordem da memória. Uma memória de olho e um olho da memória". Estas cabeças de cera, feitas para agradecer ao céu a cura desta ou daquela parte do corpo são um testemunho do contato entre corpos, es- 
pírito e memória. E o processo de teatralização dos ex-votos nas igrejas, a iluminação da matéria transparente da cera transforma esses objetos por um processo de aparição, de irradiação que emana do interior, em uma realidade divina.

\section{CONCLUSÃO}

Meu processo de transformaçăo fundamenta-se na composição e decomposição de elementos construtivos controlados por uma manipulação. A intenção está na mão, que se submete à evidência fotográfica. Ela se interpőe entre a fonte luminosa para lembrar a realidade física do efeito projetivo. Objetiva a ruptura entre a imagem e o sujeito no ato fotográfico, para poder engajar o tátil e o visual na pintura.

Parto da transformação da luz do dia para criar uma iluminação que se torna uma metáfora de tudo o que está no espaço interior da consciência. Meu projeto não pretende cobrir a questão da influência da fotografia na pintura, o que seria demasiadamente amplo. Ademais, numerosos estudos já foram feitos sobre este assunto. De minha parte, gostaria de analisar uma economia geral da iluminação em meu próprio trabalho e os conceitos de fotográfico, de transformação e de ex-voto. 
${ }^{1}$ Aubenas, Sylvie e outros, L'art du nu au XIX siècle. Paris, Hazan/Bibliothèque National de France, 1997; catálogo da exposição apresentado à Biblioteca Nacional da França, em 14 de outubro de 1997 a 18 de janeiro de 1998.

2 Didi-Huberman, Georges. L'empreinte. Paris: Gallimard, 1986, p. 75.

${ }^{3}$ Didi-Huberman, op. cit., p. 75.

${ }^{4}$ Max Kozloff, A subjetividade da fotografia, Rio de Janeiro, FUNARTE, 1986.

${ }^{5}$ Robert Grosseteste, De la lumière ou l'avènement des formes.

${ }^{6}$ Philippe Dubois, L'acte photographique, Paris, Nathan, 1990, p. 123-124.

7 Photoptica, no 10, São Paulo, outubro de 1996, p. 42-44.

${ }^{8}$ Lévi-Strauss, Tristes tropiques, Paris, Plon, 1955, p. 67.

${ }^{9}$ Lévi-Strauss, op. cit., p. 241.

10 Salgado, Sebastião, Terra, São Paulo, Companhia das Letras, 1997, p. 97-98.

${ }^{11}$ Philippe Dubois, op. cit., p. 207.

${ }^{12}$ Citada por Canclini, Nestor Garcia, na obra Feito na América Latina, Rio de Janeiro, FUNARTEMinistério da Cultura, 1981, p. 17.

${ }^{13}$ Marx e Engels usaram as metáforas "câmara escura" e "reflexo" em A ideologia alemã. Freud comparou as relações entre consciente, inconsciente e a fotografia em Metapsicologie e Nietszche em a genealogia da moral. Uma análise do tema abordado por esses autores figura na obra de Sarh Kofman, Camera Obscura — de l'idéologie, Editions Galilée, 1973.

${ }^{14}$ Marx, Karl e Engels, Friedrich, La ideologia alemana, Mexico, Ed. de cultura popular, 1977.

:5 Marx, Karl e Engels. Friedrich, op. cit., p. 26.

${ }^{16}$ Umberto Ecco, L'oeuvre ouverte, Paris, Seuil, p. 54-55.

${ }_{17}$ Schwartz Jorge, Vanguardas latino-americanas. São Paulo, Editora da Universidade de São Paulo, 1995, p. 107.

${ }^{18}$ Schneider, Luis Mario. México y el surrealismo. México, Monegal, p. 154-155.

${ }^{19}$ Schwartz. Jorge, obra citada, p. 108.

20 Schwartz, jorge, obra citada, p. 430-431.

21 Durozoi, Gérard, Histoire do mouvement surréaliste, Paris, Hazan, 1998, p.357.

${ }^{22}$ Breton, A. Frida Kahlo de Rivera, Paris, 1938.

${ }^{23}$ Krauus, Rosalind, Le photographique, Paris, Macula, p. 108. 


\section{Eduardo Vieira da Cunha}

${ }^{24}$ Breton, André, "Le surréalisme et la peinture", La révolution surréaliste, Julho, 1925, p. 26-30.

${ }^{25}$ Krauss, Rosalind, Le photographique, Paris, Macula, p. 117.

${ }^{26}$ Frank, Walter, "Tentatives de vol", in Exposé, revue d'esthétique et d'art contemporaine, vol. 2, Paris, 1995, p. 44-61.

27 Poe, E. em Colling, Alfred, E.A. Poe, Albin Michel, Nova York, 1952, p. 101.

${ }^{28}$ Krauss, Rosalind, Le photographique, Paris, Macula, 1990, p. 96.

${ }^{29}$ Dubois, Philippe, L'acte photographique. Paris, Nathan, 1990, p. 230-236.

${ }^{30}$ Debray, Régis, L'oeil naïf. Seuil, Paris, 1990, p. 279-283.

${ }^{31}$ Dubois, Philippe, op. cit., p. 279-283.

EDUARDO VIEIRA DA CUNHA: Doutorando em Artes Plásticas pela Université de Paris I - Panthéon Sorbonne, como bolsista do acordo CAPES-COFECUB entre aquela Universidade e este PPG. Realizou, de 1988 a 1990 o Master of Fine Arts noBrooklyn College de Nova lorque. Professor do Departamento de ArtesVisuais da UFRGS no setor de fotografia. Como artista plástico, participou de diversas exposições individuais e coletivas. 